\title{
SPRAWOZDANIE Z DZIAŁALNOŚCI MIĘDZYWYDZIALOWEJ KATEDRY TEOLOGII KATOLICKIEJ \\ UNIWERSYTETU W BLAEYMSTOKU (1 I 2002 - 30 IX 2003)
}

Realizując założenia statutowe jako jednostki naukowo-dydaktycznej pracownicy Międzywydziałowej Katedry Teologii Katolickiej Uniwersytetu w Białymstoku w prezentowanym okresie sprawozdawczym, w kooperacji z innymi jednostkami naukowymi, realizowali wcześniej określony na spotkaniach roboczych program pracy. Organizowali, inicjowali, bądź brali aktywny udział w sympozjach, sesjach naukowych, konferencjach i innych przedsięwzięciach naukowych mających na celu promowanie nauk teologicznych w białostockim środowisku akademickim. Mając na względzie popularyzację swego dorobku w kraju i za granicą oraz pragnąc zacieśniać współpracę z przedstawicielami nauk humanistycznych, filozoficznych i przyrodniczych MKTK podjęła w roku 2002 inicjatywę wydawniczą, uwieńczoną wydaniem pierwszego numeru Rocznika Teologii Katolickiej, stanowiącego kontynuację wydawanego dotąd Biuletynu Międzywydziałowej Katedry Teologii Katolickiej.

Wspólnym wysiłkiem Katedry Teologii Katolickiej UwB, Katedry Polityki Ekonomicznej i Rozwoju Gospodarczego UwB, Wyższej Szkoły Ekonomicznej w Białymstoku, Zakładu Bioetyki i Antropologii Filozoficznej UwB i Fundacji Promocji i Rozwoju Podlasia zorganizowano w dniach 5-7-12 III 2002 r. wykłady otwarte nt.: Globalizacja - nadzieje i lęki. Wykłady odbywały się w auli Wydziału Ekonomicznego UwB i zgodnie z przyjętą formułą skierowane były do szerokiego kręgu odbiorców, wśród których dominowali studenci i pracownicy rzeczonych jednostek naukowych. Nadspodziewanie wysoka frekwencja i obecność osób ze wszystkich niemal środowisk potwierdziła wstępne przekonanie organizatorów o potrzebie podjęcia tego tematu, właśnie w formie wykładów otwartych. Wykładom przewodniczył i dyskusję prowadził kierownik MKTK ks. bp prof. dr hab. Edward Ozorowski. Dnia 5 III prof. dr hab. R. Horodeński w wykładzie nt. Nowe oblicze podziału dóbr podjął aktualny i kontrowersyjny problem podziału dóbr, jakimi zarządza państwo, eksponując kwestię transferu środków finansowych pozyskanych drogą 
kierowania i dzielenia dobrami w kontekście mniejszych podmiotów gospodarczych. Odnosząc się do obecnej sytuacji ekonomicznej kraju wskazał na zagrożenia, jakie mogą płynąć z przyjętej polityki gospodarczej państwa. Wygłoszony tego samego dnia przez prof. dr hab. J. Kopanię wykład nt. Zagrożenia moralne $w$ dobie globalizacji dotyczył moralnego aspektu omawianego procesu. W toku swego wywodu prelegent uświadomił słuchaczom, iż podstawowym czynnikiem hamującym rozwój gospodarczy państw UE jest nadmiernie rozbudowana biurokracja, co stawia UE w niekorzystnej sytuacji względem konkurencyjnej gospodarki Stanów Zjednoczonych. Kolejny dzień wykładów (7 III) wypełniły wystąpienia prof. dr hab. W. Bieńkowskiego nt. Ekonomiczne konsekwencje globalizacji i bpa dr P. Jareckiego nt. Zjawisko bezrobocia w ocenie Kościoła. Prof. Bieńkowski w długim, fachowym, a jednocześnie ciekawym i przystępnym wywodzie dostrzegł, iż potęgujący się, zwłaszcza od 10 lat, proces globalizacji doprowadził do nienaturalnego napięcia pomiędzy rozwojem technicznym, a cywilizacyjnym, którego skutkiem jest $\mathrm{z}$ jednej strony ogromna koncentracja kapitału, z drugiej zaś coraz większe obszary biedy i bezrobocia. Stwierdził jednak, iż omawiany proces globalizacji jest nieuniknioną konsekwencją rozwoju cywilizacyjnego współczesnego świata. Bp Jarecki odwołując się do nauki społecznej Kościoła, zwłaszcza do encyklik papieża Jana XXIII Pacem in terris i papieża Jana Pawła II Laborem exercens podkreślił, iż osobowa relacja Kościoła do konkretnego człowieka zawsze kształtowała się według zasad sprawiedliwości, dobra wspólnego i podstaw ewangelicznych: miłości, prawdy i wolności. Zatem, by skutecznie przeciwstawić się zjawisku bezrobocia należy kształtować rozwój dzisiejszych społeczeństw na fundamencie nauki społecznej Kościoła. Trzeci dzień wykładów (12 III) wypełniły wystąpienia prof. dr hab. A. Bociana pt. Gospodarka Polski w procesie globalizacji, który w swoim wykładzie nakreślił wizję rozwoju gospodarki polskiej wkomponowanej w aktualny kierunek rozwoju cywilizacyjnego świata. Natomiast w czasie wykładu ks. dr D. Wojteckiego pt. Globalizacja w świetle katolickiej nauki społecznej, słuchacze zostali wprowadzeni w problematykę „relacyjności” pomiędzy wykładnią katolickiej nauki społecznej, a zachodzącym procesem globalizacji. Podsumowaniem każdego dnia wykładów była dyskusja prowadzona przez bpa E. Ozorowskiego, który reasumując cykl wystąpień wskazał na nadzieję, która - jego zdaniem - winna stanowić podstawę funkcjonowania chrześcijanina w pełnym lęków i zagrożeń współczesnym świecie.

Katedra Teologii Katolickiej była organizatorem Zjazdu Paschalnego, który odbył się dnia 13 IV 2002 r. pod hasłem Poznaj Oblicze Jezusa Chrystusa. W obradach odbywających się regularnie od 1945 r., wzięli udział katecheci duchowni i świeccy archidiecezji białostockiej. Otworzył je i przewodniczył 
im kierownik Katedry ks. bp prof. dr hab. E. Ozorowski. Zebrani wysłuchali trzech referatów. Pierwszy wygłosił kierownik Katedry Socjologii Moralności KUL ks. prof. dr hab. J. Mariański nt.: Kim dla chrześcijan w Polsce jest Jezus Chrystus. Poddając analizie zmiany w świadomości religijnej Polaków w rozumieniu Osoby Jezusa Chrystusa prelegent zauważył, iż ,Jezus przyjmowany jest dziś jako Osoba nie tyle w sensie dogmatycznym, poznawczym, ile ludzkim, emocjonalnym”. Jezus jawi się dziś - kontynuował - „w akcentach ciepła bliskości, możliwości spotkania, partnerskiego dialogu, radości życia”. Biskup pomocniczy archidiecezji częstochowskiej prof. dr hab. A. Długosz w referacie nt.: Jak dziś głosić Jezusa Chrystusa? przekonywał, iż ważnym dzisiaj jest, by nie iść do człowieka "z gotowymi receptami, nawet jeśli mamy argumenty i prawdy”. Najpierw - tłumaczył - należy nawiązać dialog, wysłuchać osoby, jej argumentów, by móc utożsamić się z konkretną osobą. „Dopiero wtedy możemy stanąć jako świadkowie Chrystusa, nie tylko jako przekaziciele pewnej prawdy, ale jako ci, co przeżywają wielką przygodę z Chrystusem" - podsumował swój wywód bp Długosz.

Przypadająca w roku 2002 dziesiąta rocznica utworzenia archidiecezji i metropolii białostockiej oraz jubileusze 75-lecia koronacji obrazu Najświętszej Maryi Panny Matki Miłosierdzia z Ostrej Bramy i 25-lecia poświęcenia kaplicy ku jej czci w archikatedrze białostockiej stały się inspiracją do spojrzenia na te i inne wydarzenia w Kościele białostockim z perspektywy minionej dekady. Uroczystości jubileuszowe rozpoczęto 31 maja uroczystą sesją zorganizowaną przez MKTK pod hasłem Wielkie wydarzenia lat 1991-1992 $w$ Kościele Białostockim. Sesję w kościele św. Wojciecha otworzył ogólną refleksją na temat rzeczonych uroczystości bp E. Ozorowski, po czym nastąpiły trzy referaty: ks. dr A. Szota nt.: Wizyta Jana Pawła II w Białymstoku, ks. dr T. Kasabuły nt.: Ustanowienie archidiecezji i metropolii białostockiej oraz ks. dr S. Hołodoka nt.: Beatyfikacja Matki Bolesławy Lament. Ukoronowaniem sesji była msza św. koncelebrowana, której przewodniczył abp dr Wojciech Ziemba, metropolita białostocki. Pełny tekst wygłoszonych referatów uzupełnionych o artykuły ks. S. Hołodoka (Archidiecezjalne Seminarium Duchowne w Białymstoku (1992-2002) i ks. T. Krahela (Rozwój kultu Matki Boskiej z Ostrej Bramy. W 75-lecie koronacji obrazu Najświętszej Maryi Ostrobramskiej w Wilnie i Białostockie Sanktuarium Najświętszej Maryi Panny Matki Miłosierdzia w Białymstoku) zostały opublikowane w bogato ilustrowanej publikacji jubileuszowej pod redakcją T. Kasabuły Witaj Królowo Matko Miłosierdzia (Białystok 2002).

Planowana od dłuższego czasu konferencja naukowa na temat transplantacji organów ludzkich odbỹła się 3 XII 2002 r. w Aula Magna Akademii Medycznej w Białymstoku. Spotkanie to, mające na celu wymianę myśli i wspólną 
refleksję na temat aktualnego dzisiaj problemu przeszczepu i popularyzacji wiedzy w tej dziedzinie, zorganizowała MKTK przy współpracy z Kliniką Nefrologii i Chorób Wewnętrznych oraz Kliniką Chirurgii Naczyń i Transplantacji Akademii Medycznej. Obrady pod hasłem Medyczne i etyczne aspekty transplantacji rozpoczął wykład kierownika Kliniki Nefrologii i Chorób Wewnętrznych AMB prof. dr hab. M. Myśliwca nt.: Transplantacja narzq̨dów u człowieka. Prelegent kompetentnie, w sposób niezwykle ciekawy i przystępny dla przeciętnego słuchacza zapoznał obecnych z aktualnym problemem transplantacji w Polsce. Poinformował jednocześnie, iż jakkolwiek $\mathrm{w}$ ciągu ostatnich lat przeszczep uznano za metodę leczenia klinicznego i liczba przeszczepów w Polsce rośnie z roku na rok, to jednak potrzeby w tej dziedzinie są coraz większe, a czas dializowania przed transplantacją np. nerki nie zmienia się od kilku lat i obecnie wynosi średnio około 2,5 roku. Dr hab. M. Gacko, kierownik Chirurgii Naczyń i Transplantacji AMB w wykładzie pt.: Chirurgiczne aspekty transplantacji nerek, ilustrując swoje wystąpienie filmem nakręconym podczas operacji przeszczepu nerki, omówił poszczególne etapy prezentowanej operacji. Na ewolucję definicji śmierci na przestrzeni ostatnich lat zwrócił uwagę kierownik Kliniki Anastezjologii i Intensywnej Terapii AMB dr n. med. A. Siemiątkowski w referacie Śmierć kliniczna a śmierć osobnicza. Ustalenie momentu śmierci jest problemem zasadniczym, jako że większość dawców organów to zmarli. O ile do niedawna za moment śmierci uznawano ustanie krążenia, o tyle dzisiaj obiektywnym kryterium śmierci jest całkowite i nieodwracalne ustanie czynności kresomózgowia i pnia mózgu. Zatem - kontynuował - „chorego można uznać za zmarłego pomimo utrzymującej się akcji serca”. Cennym dopełnieniem prezentowanych treści był wykład ks. dr hab. P. Morcińca z Uniwersytetu Opolskiego nt.: Etyczne granice transplantacji, który wyraźnie stwierdził, iż „według nauki Kościoła dawstwo organów jest czynem godnym pochwały, jest gestem bezinteresowności i heroizmu”. Zaapelował jednocześnie do „większego zaufania do transplantologii, jako do tej dziedziny medycyny, która w sytuacjach granicznych śpieszy z pomocą ludziom nieuleczalnie chorym”. Konferencja z 3 XII odbiła się pozytywnym echem w białostockim środowisku naukowym, czego wyrazem była wysoka frekwencja oraz obecność na niej rektorów wyższych uczelni, lekarzy, duchownych i licznego grona studentów a także słuchaczy nie związanych na co dzień z tą gałęzią medycyny.

MKTK włączyła się aktywnie w obchody VI Dnia Judaizmu w Kościele Katolickim. Dn. 15 I 2003 r. w kościele św. Wojciecha podczas chrześcijańsko-żydowskiej medytacji biblijnej nad tekstem 2 Sm 7, 14-15, odczytanym w języku polskim i hebrajskim, słowa Pisma Świętego komentowali: pracownik Katedry, biblista, ks. dr W. Michniewicz i współprzewodniczący Polskiej 
Rady Chrześcijan i Żydów dr S. Krajewski. Tego samego dnia w sali kina „Ton” w czasie współorganizowanej przez Katedrę konferencji naukowej nt.: Przymierze i Miłosierdzie w Tradycji Żydowskiej i Chrześcijańskiej wygłoszono dwa referaty. Honorowy przewodniczący ICCJ rabin D. Rosen (Jerozolima, ACJ) podjął temat Przymierze i Miłosierdzie w tradycji żydowskiej. Analizując przełom, jaki dokonał się w ciągu ostatnich 40 lat w Kościele katolickim w stosunku do judaizmu, rabin Rosen nazwał proces ten „rewolucją, która nie ma odpowiednika w dziejach ludzkości”. Odnosząc się do hasła tegorocznych Dni Judaizmu (Bóg zawarł z Izraelem Przymierze Miłosierdzia) stwierdził, iż „trafia ono w sedno tego, co jest wspólnym dziedzictwem judeochrześcijańskim”. Ks. prof. dr hab. H. Witczyk z KUL w referacie Przymierze i Miłosierdzie $w$ tradycji chrześcijańskiej zauważył, że jakkolwiek usprawiedliwienie dokonuje się przez włączenie się w dzieło zbawcze Jezusa Chrystusa, to do zbawienia powołany jest cały Izrael. „Miłosierdzie, jakie Bóg ostatecznie okaże całemu Izraelowi - mówił ks. prof. Witczyk - należy rozumieć jako wydarzenie, w którym mu zostanie objawiona miłość Boga. I będzie to miłość mocniejsza niż grzech nieposłuszeństwa”.

Kolejny Zjazd Paschalny z 26 IV 2003 r. zorganizowany przez Katedrę Teologii Katolickiej odbył się pod hasłem Dobro wspólne - rodzina. Konferencja naukowa, w której udział wzięli, oprócz organizatorów, katecheci świeccy i duchowni archidiecezji białostockiej, rozpoczęła się o godz. 9.00 w sali kina „Ton”. Referaty wygłosili pracownicy Katedry. Pierwsze wystąpienie ks. prof. dr hab. J. Zabielskiego poświecone było sytuacji rodziny w Polsce dziś, referat drugi wygłosił ks. bp prof. dr hab. E. Ozorowski nt.: Małżeństwo jako zwiqzzek mężczyzny i kobiety, trzeci ks. dr A. Skreczko nt.: Troska Kościoła w Polsce o rodzinę po II wojnie światowej. Pełne teksty referatów zostaną opublikowane.

W dniach 18-21 V 2003 r., pod honorowym patronatem rektora Uniwersytetu w Białymstoku prof. dr. hab. M. Gębczyńskiego, odbyła się zorganizowana z inicjatywy Zakładu Językoznawstwa Historycznego Instytutu Filologii Wschodniosłowiańskiej przy współudziale Zakładu Literatury Oświecenia i Romantyzmu Instytutu Filologii Polskiej, Katedry Teologii Katolickiej i Katedry Teologii Prawosławnej międzynarodowa konferencja naukowa nt.: Chrześcijańskie dziedzictwo duchowe narodów słowiańskich. Literatura. Kultura. Jezzyk. Obrady miały miejsce w sali konferencyjnej Centrum Kultury Prawosławnej oraz w auli Wydziału Filologicznego UwB. Udział w nich wzięli specjaliści nauk humanistycznych i teologicznych z różnych ośrodków akademickich w Polsce, Bułgarii, Rosji i na Białorusi. Konferencję rozpoczęły obrady plenarne, podczas których wygłoszono cztery referaty, wśród nich, pod nieobecność kierownika Katedry Teologii Katolickiej bpa prof. dr hab. 
E. Ozorowskiego, odczytano tekst jego wystąpienia pt.: „Mysterion” $i$ „,sacramentum" jako klucz rozumienia kultury Słowian-chrześcijan. Treść referatu wzbudziła duże zainteresowanie obecnych, jednakże z racji wyżej wspomnianych dyskusja nad nim odbyć się nie mogła. Dalsze obrady przebiegały w sekcjach: historii, językoznawstwa, literatury i onomastyki. W pierwszym dniu obrad referaty wygłosili m.in. pracownicy Katedry Teologii Katolickiej: ks. dr W. Michniewicz nt.: Semityzmy biblijne $w$ Wujkowym przekładzie Pisma Świętego na język polski (sekcja językoznawstwa) i ks. dr T. Kasabuła nt.: Drogi przenikania kultury zachodniosłowiańskiej na tereny Rusi Litewskiej ${ }_{w} X I I I-X I V W$. (sekcja historii). Wszystkie materiały z konferencji ukażą się drukiem. Uczestnicy konferencji z dnia 18 maja wzięli udział we mszy św. odprawianej w kaplicy Archidiecezjalnego Wyższego Seminarium Duchownego w Białymstoku, zwiedzili gmach uczelni i zapoznali się pokrótce z przebiegiem formacji alumnów. Następnego dnia obejrzeli spektakl w wykonaniu alumnów roku trzeciego AWSD pt. Dzień Sqdu.

Konieczność poszanowania osoby ludzkiej, troska o dobro wspólne i o etyczny wymiar życia społecznego w okresie politycznych, społecznych, gospodarczych i kulturalnych przemian w Polsce zrodziły potrzebę pogłębionej refleksji nad katolicką nauką społeczną. Znalazły się też u podstaw inicjatywy podjętej przez Katedrę Teologii Katolickiej we współpracy z AWSD i przy współudziale stowarzyszeń i ruchów katolickich Białegostoku o przeprowadzeniu cyklu wykładów otwartych dla osób zainteresowanych problematyką społeczną. W założeniu organizatorów miały one być niejako odpowiedzią na słowa papieża Jana Pawła II wygłoszone w trakcie przemówienia pożegnalnego na lotnisku w Balicach 19 VIII 2002 r.: „Niech zapanuje duch miłosierdzia, bratniej solidarności, zgody i współpracy oraz autentycznej troski o dobro naszej Ojczyzny”. Wykład inauguracyjny nt.: Człowiek drogq Kościoła wygłosił 30 X 2002 r. ks. bp prof. dr hab. E. Ozorowski. Zarówno inauguracja, jak też kolejne wykłady miały miejsce w godzinach wieczornych w siedzibie Katolickiego Stowarzyszenia „Civitas Christiana” w Białymstoku. Cykl wykładów obejmował, obok wykładu inauguracyjnego, siedem wystąpień: 27 XI 2002 r. - posła M. Jurka (Polska wobec Unii Europejskiej), 11 XII 2002 r. - ks. bpa dr S. Stefanka (Rodzina podstawowym dobrem społeczeństwa), 22 I 2003 r. - ks. prof. dr hab. J. Nagórnego (Moralny problem biedy $w$ Polsce), 26 II 2003 r. - ks. prof. dr hab. J. Zabielskiego (Miłosierdzie jako zasada życia społecznego), 19 III 2003 r. - ks. bp dr P. Jareckiego (Personalistyczno - chrześcijańska koncepcja integracji europejskiej), 9 IV 2003 - ks. dr T. Zadykowicza (Czy może istnieć świat bez wartości?), 21 V 2003 r. dr T. Żeleźnika (Czy może istnieć wolność bez prawdy i sprawiedliwości?). Pełne teksty wykładów są publikowane w postaci zeszytów w serii wydawni- 
czej „Biblioteka Wykładów Otwartych z Katolickiej Nauki Społecznej” przez podlaski oddział „Civitas Christiana”. Wysoka frekwencja i duże zainteresowanie środowisk tą inicjatywą skłoniło organizatorów ku decyzji o kontynuowaniu wykładów otwartych także w roku akademickim 2003/2004.

Pracownicy MKTK, jako jednostki naukowo-badawczej w strukturach UwB, podejmują działalność dydaktyczną prowadząc wykłady, ćwiczenia i seminaria naukowe zarówno na UwB, jak też na innych uczelniach. W ramach działalności statutowej i własnej kontynuowali prace badawcze w swoich dziedzinach, organizowali, współorganizowali i uczestniczyli w zjazdach, sympozjach i konferencjach naukowych dotyczących tych dziedzin, które leżą w zakresie ich zainteresowań. Rezultat tej aktywności to dorobek piśmienniczy w postaci druków zwartych i artykułów w czasopismach stricte naukowych i popularnonaukowych, których wykaz, chociaż niepełny, znajduje się na stronie internetowej Katedry. Wykaz publikacji za rok akademicki 2001/ 2002 zamieszczono też na łamach WKAB (11: 2002, nr 4, s. 270-299). Godnym odnotowania jest fakt, iż ks. dr Adam Skreczko - pracownik Katedry pomyślnie przeprowadził przewód habilitacyjny na podstawie dysertacji Troska Kościoła katolickiego w Polsce o małżeństwo i rodzinę w okresie Wielkiej Nowenny (1957-1966). Studium teologiczno-pastoralne.

Z wolna posuwają się badania nad językiem teologicznym, których zwieńczeniem ma być Słownik Pojęć Chrześcijańskich, inicjatywa podjęta przed dwoma laty przez Katedrę.

W roku akademickim 2003/2004 rozpocznie się kolejny rok studiów w powołanym do życia z inicjatywy MKTK Podyplomowym Studium Metodyczno-Katechetycznym przy UwB. Kierownikiem Studium został ks. dr Adam Skreczko, który zajął się stroną organizacyjną tej jednostki dydaktycznej i z powodzeniem koordynuje jej działalność. Kolegium wykładowców stanowią wszyscy pracownicy Katedry oraz pracownicy naukowi innych środowisk naukowych regionu.

Koordynacji własnych prac badawczych, dyskusji nad aktualnymi pracami Katedry i podejmowaniu inicjatyw naukowych służą comiesięczne spotkania robocze wszystkich pracowników MKTK, prowadzone według porządku ustalanego każdorazowo przez kierownika Katedry. 